\title{
Ekolojik Sanat: Çevre Eğitimi İle Sanatın Kesişme Noktası*
}

\author{
Ecological Art: The Intersection Point of Environmental \\ Education and Art
}

\begin{abstract}
Nuray MAMUR**
Öz: Ekoloji temelli sanat üretimleri 1960'ların sonlarından 1980'lere çevresel sanat hareketlerinden özellikle yeryüzü ve arazi çalışmalarından etkilenilerek ortaya çıkmıştır. Ekoloji sanatçıları sanattaki bilinen yöntemlerin ve araç gereçlerin dışında çalışmışlardır. Bazıları doğada bulduğu malzemeleri biçimlendirmeyi, bazıları da atık malzemeyi kullanmayı ve onları yeniden dönüştürmeyi tercih etmiştir. Bazı sanatçılar ise disiplinler arası bir yaklaşımla eğitim dokümanlarını kullanmış ve küresel düzeydeki çevresel problemlere yerel çözüm üretebilecek yöntemler geliştirmeye çalışmıştır. Çoğu ekolojik sanatçı da küresel ve çevresel endişelerin toplum ve yaşam merkezli olmasından dolayı çevresel aktivitelerinde ve ekolojik temelli sanat çalışmalarında özellikle insanlara odaklanmıştır. Yapmış oldukları çalışmalarda metafor ya da mizah yoluyla insanları uyarmaya çalışmışlardır. Özellikle doğa ve sosyal yaşam arasındaki temasta ortaya çıkan çevresel problemlere dikkati çekmişler, doğaya dönük bilinç oluşturmada ekolojik restorasyon kadar, kültürel bir restorasyonunda gerekliliğine işaret etmişlerdir. Çünkü onlara göre sürdürülebilir yaşam biçimi; hem ekolojik hem de kültürel restorasyonla mümkündür ve sanat ekolojik duyarlılık konusunda farklılık yaratabilecek bir güce sahiptir.

Bu çalışmada, öncelikle çevre meseleleri ile ilgili doğrudan mesaj veren ya da insanlığı sürdürülebilirlik üzerine düşünmeye davet eden sanatçıların eserlerine odaklanılmıştır. Joseph Beuys, Yoko Ono, Andy Goldsworthy, Mierle Ukeles, David Hansen, Mel Chin, Maro Michalakakos gibi sanatçıların çalışmaları üzerine yapılan betimsel analiz çerçevesinde ekoloji ve sürdürülebilir sanat uygulamaları ile çevresel sorumluluğa dikkat çekmek istenmiştir. Araştırmada sanatçıların eserleri üzerinden çalışılan durumun genel bir resmi çıkarıldıktan sonra sürdürülebilirlik ve ekolojik konularla ilgili endişelerin sanat eğitiminde teori ve uygulama bazında nasıl ele alındığı ve alınabileceği konusunda değerlendirmelerde bulunulmuştur.

Anahtar Kelimeler: Görsel sanatlar eğitimi, çevre eğitimi, sürdürülebilir gelişim, ekolojik ayak izi, çevre sorunları
\end{abstract}

\begin{abstract}
Ecology based art production emerged from the end 1960s to 1980s by the effect of environmental art movements particularly earth and land work. Ecology artists have worked out of the known techniques and tools in art. Some preferred shaping the materials found in nature whereas others used waste materials and recycled them. Some artists, on the other hand, had an interdisciplinary approach and used educational documents and tried to develop solutions to a global level environmental problem. Many ecological artists particularly focused on human in their environmental activities and ecology based art works as global and environmental matters are society and life centered. In their works they tried to warn people through metaphor and humor. They attract attention particularly to environmental problems that occur due to interactions between nature and social life, and also state that cultural restoration is necessary as much as nature concerned ecological restoration. Because according to them, sustainable life style is possible only through both ecological and cultural restoration and art has the power to make difference in ecological sensibility.

This study particularly focuses on the pieces of artists who directly give messages about environmental issues or invite people to think about sustainability. Within the scope of a descriptive analysis on artists' work such as Joseph Beuys, Yoko Ono, Andy Goldsworthy, Mierle Ukeles, David Hansen, Mel Chin, Maro Michalakakos the aim was to draw people's attention to environmental responsibilities through ecology and sustainable art practices. In this study, after the artists' works were analyzed in general based

\footnotetext{
*Bu çalışma 11-14 Mayıs 2017 tarihlerinde Pamukkale Üniversitesi’nde düzenlenen 4. International Eurasian Educational Research Congress'nde sözlü bildiri olarak sunulmuştur.

**Doç. Dr., Pamukkale Üniversitesi, Eğitim Fakültesi, Güzel Sanatlar Eğitimi Bölümü, Denizli, e-posta: nmamur@pau.edu.tr
} 
on the issues they work on, evaluations were made about how sustainability and ecologic issues could be handled on theory and application level in art education.

Keywords: Visual art education, Environmental education, Sustainable development, The ecological footprint, Environmental problems

\section{Giriş}

Son yıllarda sanat araştırmalarında ve sanat üretimlerinde çevre bilinci ile sanatın kesiştiği görülür. Sanatçılar eserleri yoluyla dünyanın ekolojik ve çevresel bütünlüğünün korunmasına dönük bir algı oluşturmaya odaklanmaktadır. Aynı şekilde bu ekolojik sanat üretimlerine paralel olarak sanat eğitimcilerinin de ekoloji ve sürdürülebilirlik bağlamında çevresel konulara odaklanarak kuramsal bir yapı oluşturmaya giriştikleri görülmektedir. $\mathrm{Bu}$ girişimler "Toplum temelli ekolojik sanat eğitimi" (Neperud, 1997), "Ekolojik sanat öğretimi" (Hollis, 1997) ve "Sanat yoluyla çevre eğitimi" (Stankiewicz ve Krug, 1997), gibi adlarla alan yazında yerini almıştır. Bu yönelişin altında, 1960'ların sonu itibariyle başlayan çevresel sanat hareketlerinin ve eğitimde sosyal yapılandırmacı yaklaşımlar temelinde öğretim programlarındaki disiplinler arası etkileşimlerin artması ve sürdürülebilir kalkınma eğitiminin olduğu söylenebilir.

Sanat alanında çevre hareketlerinin ortaya çıkışı 20. Yüzyıl'da, bilim ve teknoloji alanındaki ilerlemelerle birlikte var olan modern toplumun doğa ile barışı olmayan kalkınma ve insan merkezli yaklaşımlarının, kültürel ve ekonomik değerlere de yansıyarak, dünyayı ekolojik bir krize sürüklemesinin bir sonucudur. Küresel 1sınma, tatlı su kaynakların kirlenmesi, orman ve tarım arazilerinin yok edilmesi, erozyon, nüfus artışı, yeni hastalıklar ve açlık tehdidi gibi birçok çevresel sorun, 20. Yüzyıl'ın ikinci yarısından itibaren tüm dünyada sıklıkla gündeme gelmeye başlamıştır. Sanatçılar da toplumsal yaşamda tüketim odaklı ve ekonomik olarak sürekli büyüme anlayışına sahip yaklaşımların hem çevre hem de insanın varlığı için oluşturduğu potansiyel risklere kayıtsız kalamamışlar, disiplinler arası yaklaşımlarla çevre sorunlarını eserlerinde tartışmaya açmışlardır. Stankiewicz ve Krug'un (1997) deyimiyle sanat ve ekoloji çevresel problemleri tanımlamak ve bunların nasıl restore edileceği konusunda işbirliğine gitmiştir. Çevresel endişelerin toplum ve yaşam merkezli olması da ekoloji temelli sanat çalışmalarına sosyal bir işlev yüklemiştir. Nitekim çoğu ekolojik sanatçı çevresel aktivitelerinde genellikle insanlara odaklanmıştır. Yapmış oldukları çalışmalarda metaforlar yoluyla insanları uyarmaya çalışmışlardır (Stankiewicz ve Krug, 1997).

$\mathrm{Bu}$ çalışmada iki soru bağlamında yapılandırılmıştır? Birincisi, sanatçıların ekoloji temelli sanat uygulamalarında çevresel sorumluluğu ele alma biçimleri nasıldır?, İkincisi, sürdürülebilirlik ve ekolojik konularla ilgili endişeler sanat eğitiminde kuramsal ve uygulama bazında nasıl ele alınabilir?

\section{Yöntem}

Bu çalışmada, öncelikle çevre meseleleri ile ilgili doğrudan mesaj veren ya da insanlığı sürdürülebilirlik üzerine düşünmeye davet eden sanatçıların eserlerine odaklanılmıştır. Araştırma kapsamında çevresel sanatın öncüsü olarak kabul edilebilecek Robert Smithson, Joseph Beuys gibi sanatçılar ile ekolojik sanat konusunda farkındalık yaratmaya çalışan "greenmuseum.org" adresindeki çok sayıda sanatçı arasından seçilen 8 sanatçı ile birlikte toplam 10 sanatçı belirlenmiştir. Andy Goldsworthy, Lynne Hull, Mierle Laderman Ukeles, Helen Mayer ve Newton Harrison, Agnes Denes, Mel Chin, Nele Azevedo, Yoko Ono gibi sanatçıların ekoloji temelli sanat uygulamalarında çevresel sorumluluğu ele alma biçimleri çözümlenmiştir. $\mathrm{Bu}$ sanatçıların belirlenmesinde amaçlı örnekleme yöntemlerinden ölçüt örnekleme kullanılmıştır. Bu kapsamda araştırmacı tarafından belirlenen ölçütler; sanatçıların çalışmalarında, ekosistem ile insanlar arasındaki etkileşime eğilmeleri ve ekosisteme bakışlarının birbirlerinden farklı yöntem ve tekniklerle farkındalık ve saygı temelinde yorumlanmasıdır. Araştırmada doküman analizi çerçevesinde sanatçıların eserleri üzerinden çalışılan durumun genel bir resmi çıkarıldıktan sonra ikinci bölümünde sürdürülebilirlik ve ekolojik konularla ilgili endişelerin sanat eğitiminde teori ve uygulama bazında nasıl ele alındığı ve alınabileceği konusunda değerlendirmelere yer verilmiştir. 


\section{Bulgular}

Araştırmada ekoloji sanatçılarının ussal ve düşsel bakış açılarını yansıttıkları üretimleri çerçevesinde ilgili alan yazından elde edilen bulgular; Sanatta çevre hareketleri ve ekolojik sanat ile sanat yoluyla çevre eğitimi başlıkları altında sunulmuştur.

\section{Sanatta Çevre Hareketleri ve Ekolojik Sanat}

"Doğa" mağara dönemindeki primitif tasvirlerden bu yana her dönem birçok sanat eserine esin kaynağı olmuştur. Manzara resmi, ana konunun mekânı ya da ilham kaynağı olarak her dönem sanatçının odağına yerleşmiştir. Ancak sanatta “doğa” temsillerinin 1960'ların sonlarından itibaren farklı bir boyut kazanarak dönüştügü görülür. Bunda 1960'larda dönemin sosyal yapısında meydana gelen değişimlerin etkisi büyüktür. Sanatçıların kültür tarihi, sosyoloji, politika, bilim ve teknoloji konulu araştırmalara dayanarak dünyayla ilişki kurma biçimlerindeki değişim, sanattaki doğa temsilinin toplumsal ve politik algılarla doğrudan bağlantılı hale gelmesine neden olmuştur. Post modern eleştirel teorinin gelişimi genel doğa anlayışını da etkileyerek insanlar ile eko-sistem arasındaki etkileşime eğilen sanat çalışmalarının yolunu açmıştır (Bafra ve Colombo, 2016). Sanatçılar "doğada açık alanları kullanmaktan, doğal materyallerin kullanımına, çevresel farkındalığı arttırmaya, restorasyon, geri dönüşüm, yenilenme, mekana özgü projelere kadar farklı uygulamalara" (Aydın ve Zümrüt, 2013, s. 53) yönelerek doğal süreçlerle ilgili endişelerini dile getirmede sanatı kullanmışlardır. Bu çalışmalar "Arazi Sanatı", "Yeryüzü Sanatı", "Toprak Sanatı", "Çevresel Sanat", "Ekolojik Sanat" gibi çeşitli adlandırmalarla sanat tarihinde yerini almıştır. Bu terim ve tanımlamalar arasında tam bir sınırlama yapılamamasına rağmen, kullanılan malzeme ve amaçları konusunda aralarında farklılıklar söz konusudur (Aydın ve Zümrüt, 2013). Ancak doğaya dönük bilinç oluşturma, çevre sorunları ve modern insanın doğayla arasına koyduğu mesafeyi yıkma konusunda benzer kaygıları vardır. "Bu sanatçılar teknoloji-insan-doğa ilişkisini yeniden sorgulamaya başlayarak gözlerini alışılmışın dışında yeni bir bilinçle, yeni bir bakış açısıyla doğaya çevirmişlerdir" (Bilir, 2014, s. 23). 1960'lardan günümüze kadar uzanan süreçte de gelişen ve değişen "çevre" düşüncesi ve algısı, ekosistemi içeren, çevre sorunlarını kapsayan kaygılara doğru evrilen çok farklı sanat oluşumlarını getirmiştir. Bunlar; 'Art in Nature', 'Eco-art', 'Green Art', 'Restoration Art', 'Ecoventions', 'Sustainable Art', gibi örneklenebilecek, çok sayıda ve çeşitlilikte bir yelpaze oluşturmaktadır (Ataseven, 2016). Günümüzde çevre ve doğa sorunlarını merkeze alan bu çalışmaları isimlendirmek için şemsiye bir terim olarak genellikle "Ekolojik sanat (Eco-art)" ya da "Çevresel sanat" isimlendirmelerinin kullanıldığ 1 görülmektedir. Alan yazında (Bower, 2010) bu iki kavram arasında tartışmalar devam etmektedir. "Çünkü "Ekoloji" sözcüğü daha çok ekosisteme ve biyolojik döngüye gönderme yaparken, "çevresel” sözcüğü kâğıtların geri dönüşümü, enerji politikaları gibi konuları içerebilen daha genel bir ifadeye karş11k gelmektedir" (Ataseven, 2016, s. 273).

Çevre bağlamında sanat uygulamalarının ilk örnekleri 1960'larda arazi sanatı ya da yeryüzü sanatı kapsamında esasen minimal sanatın basit detaylandırılmamış formlarına karşı bir memnuniyetsizliğin sonucu olarak ortaya çıkmıştır. Minimal sanatın sanayi kültürünün gelişmiş teknolojik ürünleriyle yaptıkları düzenlemeler arazi ve yeryüzü sanatı yoluyla eleştirilmiştir (Krug, Blandy ve Congdon, 1998). Başlangıçta galeri mekânlarını terk etme kaygısıyla yola çıkan sanatçılar sonrasında yeryüzüne acilen sahip çıkılması ona sayg1 duyma noktasında farkındalık yaratmayı hedeflemişlerdir. "Yeryüzü sanatının ilk örneklerini veren Roberth Smithson araziyi bir nevi operasyon aracı olarak kullanmıştır. Smithson'ın sanatı sorgulaması, doğal kirlenmeye karşı tutumuyla bağlantılı bir şekilde gelişmiştir" (Yılmaz, 2013, s. 309). Smithson'a göre; "Ekonomi dünyadan soyutlandığında, doğal süreçlere kördür. Sanat, çevreciyle endüstrici arasında iletişimi sağlayan bir kaynağa dönüştürülebilir. Çevre bilinci ve endüstri iki ayrı çıkmaz yol gibi değil, birbiriyle bir noktada kesişen yollar gibi düşünülmelidir. Sanat ikisi arasında gerekli olan diyalektik ilişkiyi sağlayabilir" (Antmen, 2009, s. 259). Sanat çevre için insanları harekete geçirmek için kullanılabilir. Örneğin; Smithson'ın ABD'de Utah Eyaleti'ndeki tuz gölünün kenarında taş ve toprakla gerçekleştirdiği "Spiral Jetty (Sarmal Dalgakıran)" adlı eser ekolojik sanat hareketinin öncü çalışmalarından biridir. Ekolojik sslah 
çalışması olarak bahsedilen bu çalışma, petrol çıkarmak için kullanılmış ve zarar görmüş bir eko-sistem üzerinde gerçekleştirilmiştir.

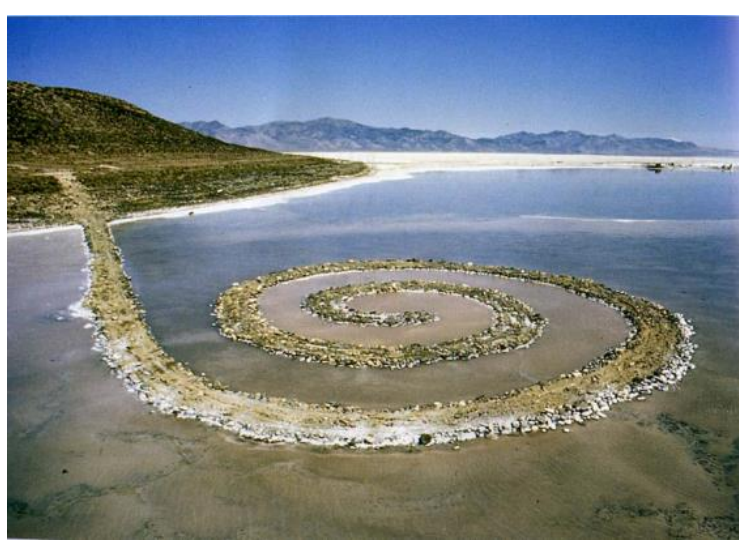

Görsel 1. Roberth Smithson, Spiral Jetty, 1970

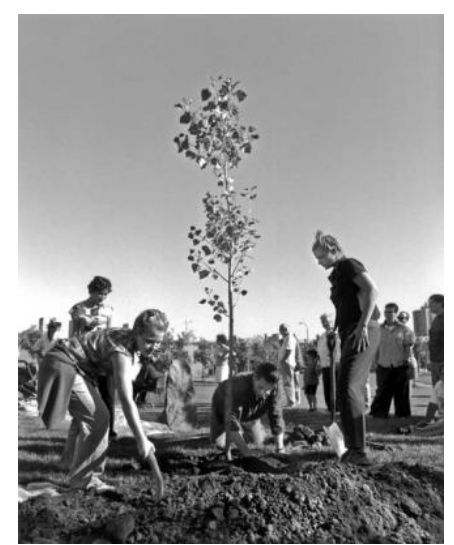

Görsel 2. Joseph Beuys, 7000 Oaks 7000 Basalt, 1982-1987

Jeoloji ve manzaranın kendisiyle ilgilenen, geniş arazilerde sanat çalışmaları yapan Michael Heizer ve Walter De Maria gibi sanatçılar da halkın izleyemeyeceği, göremeyeceği 1ssız alanları, kayalıkları mekân olarak seçmişlerdir. Ancak galeri-sanat yapıtı algısını değiştirerek, doğaya ilişkin bilinç oluşturma yaklaşımlarının Joseph Beuys gibi sanatçıların çalışmalarıyla değişmeye başladığı görülür. 1960'larda Beuys yeryüzünün korunmasını talep eden politik demeçler vermeye başlar. Beuys, sanat ve yaşamı kültür, doğa ve ekolojik sistem olarak birbiriyle ilişkilendiren bir sanatçıdır (Krug, Blandy ve Congdon, 1998). Sanatçının 7. Dokumenta etkinlikleri kapsamında Kassel'da 1982-1987 yılları arasında gerçekleştirmiş olduğu "7000 Meşe, 7000 Bazalt" adlı çalışması toplumsal ve çevreci sorumluluk bilinciyle yaptığı tasarımlarından sadece bir tanesidir. Sanatçı hızlı sanayileşme yüzünden bozulan Kassel'in doğal dengesini 7000 meşe ağacı dikerek onarmak istemiştir. Çalışmada bazalt taş1 durağanlık, sağlamlık ve katılığı, çok yavaş büyüyen meşe ağacı ise doğal ve toplumsal varlığ simgelemiştir. Bu etkinlikte ağaç dikme etkinliğine katılan her insan ise yaşadığı çevrenin biçimlendiricisi olmuştur (Yılmaz, 2013).

"Tüm bu girişimler değişime etki etmeyi, iyileştirmeyi, onarmayı, geri dönüşümü amaçlayan disiplinler arası bir hareket olan ekolojik sanatı beraberinde getirmiştir" (Aydın ve Zümrüt, 2013, s. 56). Ekolojik sanat felsefesi ekolojik bilinç, insan ve doğanın uyumlu birlikteliği üzerine temellenen evrensel bir harekettir (Bianco, 2000). Ekoloji bilgisi ile de küresel sorunların giderilmesi ve toplumsal bir bilincinin oluşturulması amaçlanmaktadır (Türe, 2013). Bu nedenle ekolojik sanat, çevresel sorunlara hitap eden ve genellikle ortaklaşa çalışma, onarım, yenileme kavramlarını içeren, çoğunlukla çevre dostu yaklaşımları ve yöntemleri olan bir çağdaş sanat akımı olarak tanımlanmaktadır (Ataseven, 2016). "Günümüzde ortaya çıkan ekolojik sanat uygulamalarının temelinde de, dünyanın ekolojik ve çevresel bütünselliğinin korunması algısı bulunmaktadır"(Türe, 2014, s. 227). Genellikle bu sanat çalışmalarının özünde bilimsel konulara gönderme söz konusudur. Çalışmalarda yaşayan bir ekosisteme odaklanıldığ için sanatçılar özellikle şehir planlamacıları, sosyal bilimciler, biyologlar, botanikçiler ve çeşitli sivil toplum kuruluşları ile işbirliği içinde çalışarak projeler üretmişlerdir (Aydın ve Zümrüt, 2013).

Ekolojik sanat üretimlerinde kullanılan malzemeler geleneksel sanatın sınırlarını aşan bir özelliğe sahiptir. Sanatçıların çoğunlukla sıradan, doğal ve geri dönüşümlü materyalleri kullandığ görülmektedir. Ancak sanatçılar ekolojik ve kültürel restorasyonla da ilgilendikleri için metinleri, fotoğrafları çeşitli bilimsel raporları kirlenmiş ve hasar görmüş alanlara insanların dikkatini çekmek ve o alanları yeniden kazanmak için kullanmışlardır. Örneğin; sıradan doğal materyallerle çalışan Andy Goldsworthy, çalışmalarında görünenin altına inerek doğanın işleyiş 
mantı̆̆ını keşfetmeyi amaçlamıştır (Yılmaz, 2013). Goldsworthy, doğada yok olabilen zararsız dokunuşlarla ilerlemeyi tercih eden bir sanatçıdır. "Sanatçının malzemesi doğanın kendisi, çalışmalarına hayat veren ise mevsimsel süreçlerdir. Amacı estetik bir kaygıyla, doğaya farkındalığı sağlamak düşündürmek, hissettirmektir. Çalışmaları yapım sürecinde de sonrasında da doğaya zarar verir nitelikte değildir" (Aydın ve Zümrüt, 2013, s. 62). Sanatçının 2000 yılında gerçekleştirdiği "Kartopu" adlı uygulamaları doğa ve endüstri ilişkisine gönderme yapan bir çalışmadır. "Sanatçı İskoçya'nın dağlarından getirilen 13 tane 2 metre çapında ve bir ton ağırlığında olan kartoplarını doğanın yıkımını eleştirmek amacıyla çeşitli fabrikaların önüne koymuştur. Her bir kartopunun içinde doğa, tarım ve endüstri ile ilişkilendirdiği bir materyal bulunmaktadır. Örneğin; İskoç sığırlarının kıllarının olduğu kartopunu bir et fabrikasının girişine koymuştur (Oğuz, 2015).
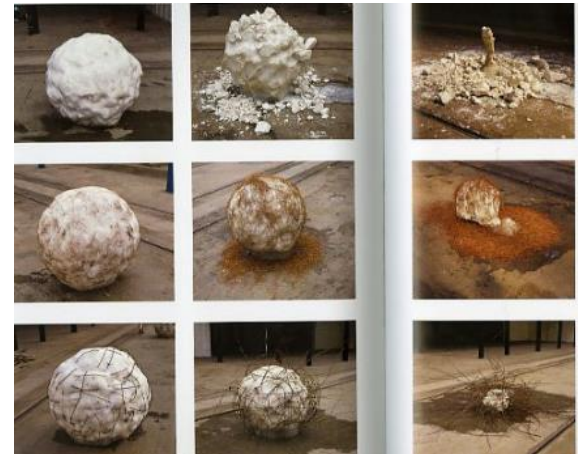

Görsel 3. Andy Goldsworthy ve Snowballs, 2000
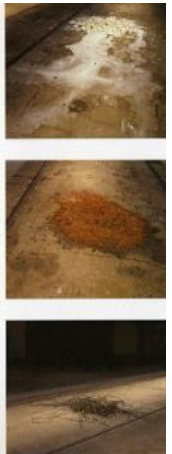

Görsel 4. Andy Goldsworthy,

Emhemeral Works, 2004-2014

Bir diğer sanatçı Lynne Hull'un çalışmalarında ise doğayı yeniden kazanmaya dönük öneriler gizlidir. Sanatçı vahşi yaşam alanlarının sürdürülebilirliğine ilişkin yapmış olduğu çalışmalarda estetik kaygı kadar işlevselliği ön planda tutmuştur. Vahşi yaşam alanlarında yapmış olduğu küçük iyileştirmeler, bir çeşit hayvanlar için sanat etkinliği gibidir. "Sanatçı "Lightning Raptor Roost" adlı çalışmasında göçmen kuşların konaklayabilmesi için bir dizi güvenli yer oluşturmuştur. Bu çalışma sonrasında yapılan araştırmada şahinlerin, baykuş ve kartalların buralarda yuva yaptığı kanıtlanmıştır" (Aydın ve Zümrüt, 2013, s. 63). Sanatçı "Sanat ve İklim değişikliğì" adlı bir sergide ise "Vahşi Uyarı", "Vahşi Hayat" yazan uyarı tabelaları ile küresel 1sınma yüzünden ilk yok olacak canlı türlerine dikkat çekmek istemiştir (Oğuz, 2015).

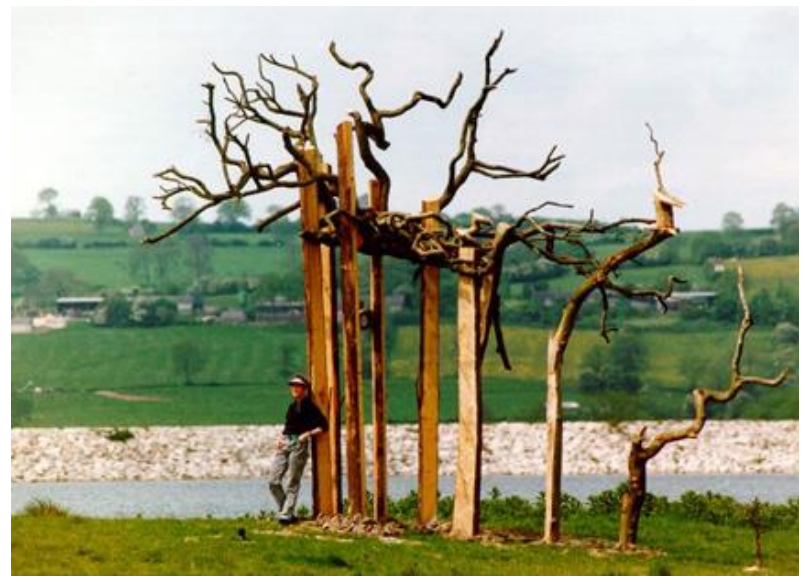

Görsel 5. Lynne Hull, Lightning Raptor Roost, 1994

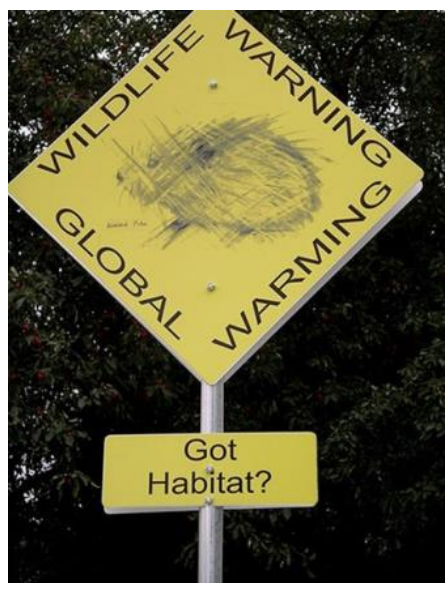

Görsel 6. Lynne Hull, Wildlife Wraning Signs, 2009 
Ekolojik sanat üretimleri ile dikkat çeken ve ortaklaşa çalışan Helen ve Newton Harrison ise yapmış oldukları çalışmalarda küresel ısınma ve ozon tabakasındaki deliğin toplumsal ekosistemler üzerindeki etkilerine odaklanmışlardır. Onlar küresel problemler için yerel çözümler önermişlerdir (Krug, Blandy ve Congdon, 1998). Projelerinden birinde Doğu Avrupa'nın en kirli nehirlerinden biri olan Sava River için "Green Zone"1 yaratmışlardır. Projelerinin tamamı plan, harita, diyagram, çizim ve fotoğrafların kullanıldığı düzenlemelerden oluşmuştur. İşbirlikli çalışan bu iki sanatçı, proje sonunda önerilerinin bir kısmının gerçekleşmesini sağlamışlardır.

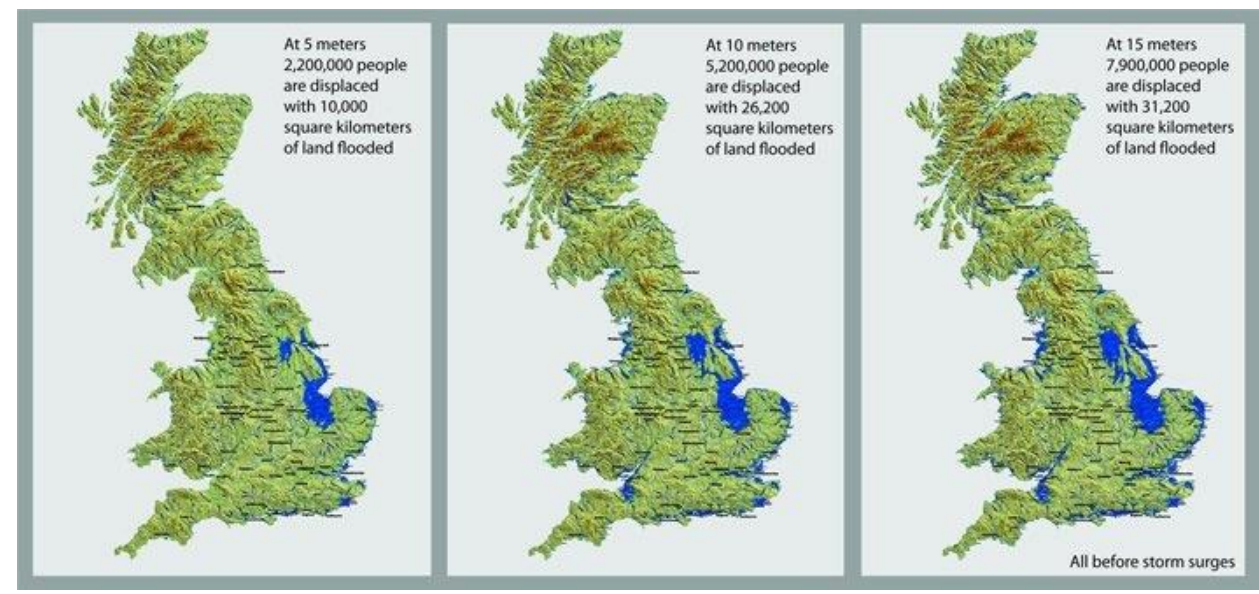

Görsel 7. Helen ve Newton Harrison, Green Zone, 2009

Mierle Laderman Ukeles çoğunlukla sosyal, politik, çevresel ve feminist teorinin bağlamı içinde sanat ve yaşamı birleşimi eserlere odaklanmıştır. Sanatçı özellikle tek kullanımlık çöpleri büyüyen bir problem olarak görmüş ve insan katılımına dayalı çalışmalarında atık materyallere odaklanmıştır (Krug, Blandy ve Congdon, 1998). "Flow City" adlı çalışmasında kentsel ekosistemi yeniden kavramsallaştırarak sanat yoluyla pozitif bir değişim yaratmak istemiştir. Nitekim Ukeles'e (2000) göre; en önemli peyzajlar durgun olanlar değil, hayatın akışını anlatanlardır" (aktaran Oğuz, 2015). Sanatçı New York şehrinde katı atık yönetimi konusunda vatandaşları bilinçlendirmeye çalışmıştır. Böylelikle doğa-kültür diyalektiğinin önemini gözler önüne sermek istemiştir.

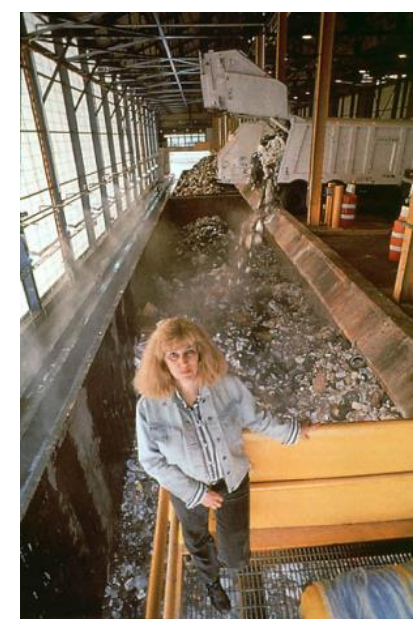

Görsel 8. Mierle L. Ukeles, Flow City, 1983

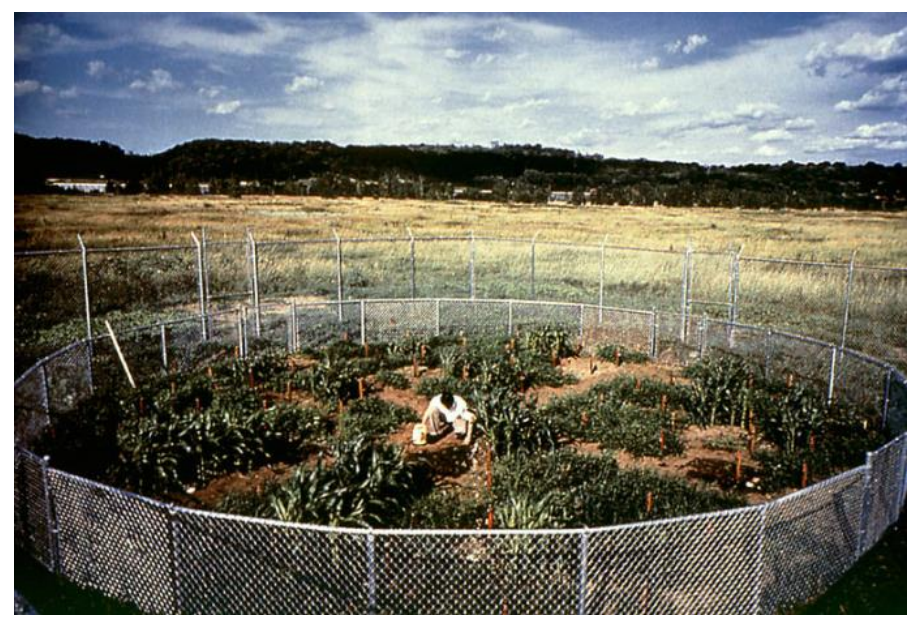

Görsel 9. Mel Chin, Revival Field, 1990 
Sanat yaşamının ilk yıllarında politik ve sosyal konular ekseninde heykel çalışmaları yapan Mel Chin ise sonrasında çalışmalarını ekosistem ve sürdürülebilirlik üzerinden genişleterek habitatın harabı, restorasyon ve yeryüzündeki biyoçeşitliliğin sürdürülebilirliği üzerine odaklamıştır. "Beuys gibi yapıtının kendinden sonrada devam edebilmesi sürecine hayran olan Chin, gerçekleştirdiği işin kendi başına devam edebilmesiyle ilgilenmiştir" (Oğuz, 2015, s. 59). 1990 yılında gerçekleştirdiği "Revival Field (Hayata Dönüş Alanı)" adlı çalışmasında kontemine olmuş bir toprağı arındırmıştır. Onun bu ekolojik restorasyon çalışması Minneapolis bulunan Walker Sanat Merkezi tarafından desteklenmiştir. Rufus L. Chaney adlı bir bilim adamıyla işbirlikçi çalışmasının sonucunda etrafi çitlerle örülmüş zehirli atık yığınlarının olduğu bir bölgeyi yeniden canlandırmıştır. Bunun için Chaney ve Chin öncelikle yerel ekosisteme uygun metali ve minareli içinde tutabilme özelliğine sahip bitkileri araştırmıştır. Bitkilerle süreç içerisinde ilgilenilmiş, gerekli bakımları yapılmış ve yapılan incelemeler sonunda tüm alanın zehirden arındığı tespit edilmiştir.
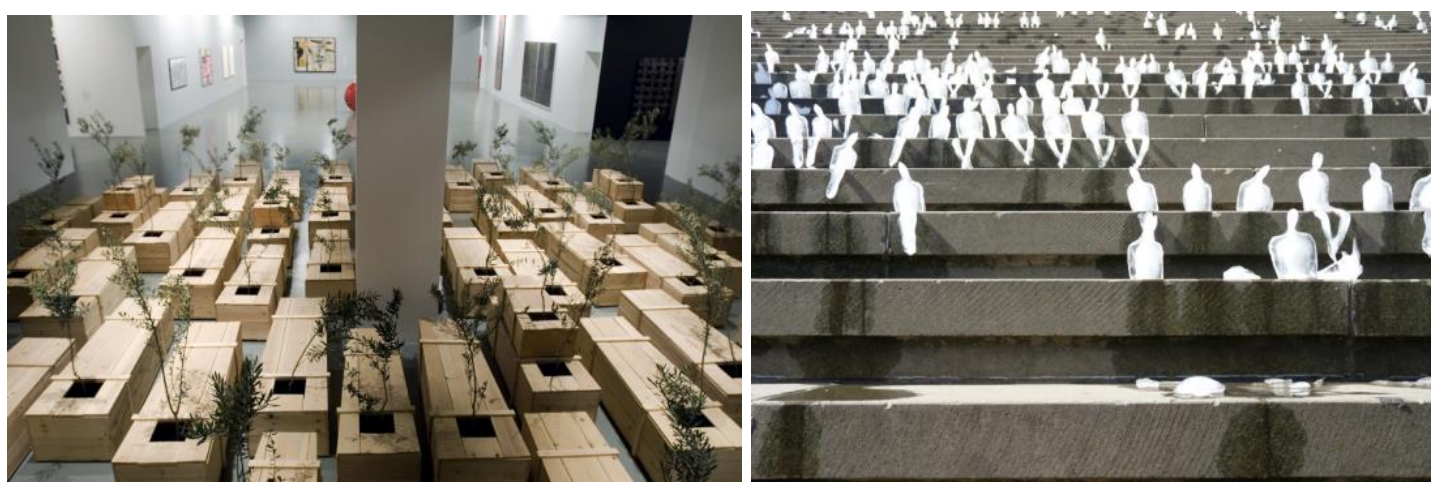

Görsel 10. Yoko Ono, Ex It, 1997-2007

Görsel 11. Nele Avezedo, Melting Men, 2009

Yoko Ono farklı alanlarda ortaya koyduğu çalışmalarıyla tanınan bir sanatçıdır. Zeytin ağac1 ve çeşitli ölçülerde 50 ahşap tabutla yaptığ1 "Ex It" (1997-2007)adlı çalışması mekâna özgü bir yerleştirmedir. Basit ve kaba işçilikle yapıldığı belli olan tabutlar doğal bir felaket ya da savaş sonrasında aceleyle kurulan bir toplu mezarı çağrıştırır. Kuş sesleri ile hareketlenen mekândaki her bir tabutun kapağındaki boşluktan uzanan ve gün geçtikçe büyüyen zeytin ağacı fidanları görülür. Çalışmada tabut ölümü, zeytin ağacı yeniden dirilişi, kuş sesleri ise doğanın gücüne ve enerjisine işaret etmektedir (Bafra ve Colombo, 2016). Sanatçının doğanın gücüne ve enerjisine olan inancı geleceğe dair bir iyimserliği barındırmaktadır.

Brezilyalı sanatçı Nele Avezedo ise yerkürenin kırılganlığına ve küresel iklim değişikliğine dikkatleri çekmek isteyen bir sanatçıdır. Sanatçı 2009 yılında Berlin Konser salonunun merdivenlerinde sergilemek için $20 \mathrm{~cm}$ boyutlarında 1000 adet buzdan heykelle bir enstelasyon oluşturmuştur. Kamusal alanda gerçekleştirilen çalışma, herkesin gözü önünde 30 dakikada suya dönüşmüştür. Küresel ısınmaya ve büyük çevre felaketlerine dikkat çekilmek istenen bu çalışma, sonraları dünyanın farklı yerlerinde birçok kez tekrarlanmıştır (Türe, 2014). Macar asıllı sanatçı Agnes Denes ise çalışmalarında insan ve doğa ilişkisini temel almaktadır. Geniş devasa mekânlarda çalışmayı tercih eden sanatçının en çok ses getiren projelerinden biri Buğday Tarlaları: Yüzleşme'dir. Sanatçı Manhattan'daki Wall Street ve Dünya Ticaret Merkezinin yakınına yaklaşık 8 km'lik araziye buğday ekmiştir. Sanatçının bu projesiyle büyük bir paradoksu gözler önüne sermek istemiştir. Buğday gıda, enerji, ekonomi ve ticaret gibi dünya piyasalarının nabzını tutan birçok farklı sektör için ana hammadde olmasının yanı sıra, oldukça kilit bir üründür. Çünkü buğday, dünyadaki açlığı giderebilecek en önemli gida olan ekmeğin ve tüm hamur işlerinin yapımında kullanılan unun hammaddesidir. İnsanlar onun önemini göz ardı etmektedir ve bu durumla yüzleşmeleri gerekmektedir (Denes, 2015) 

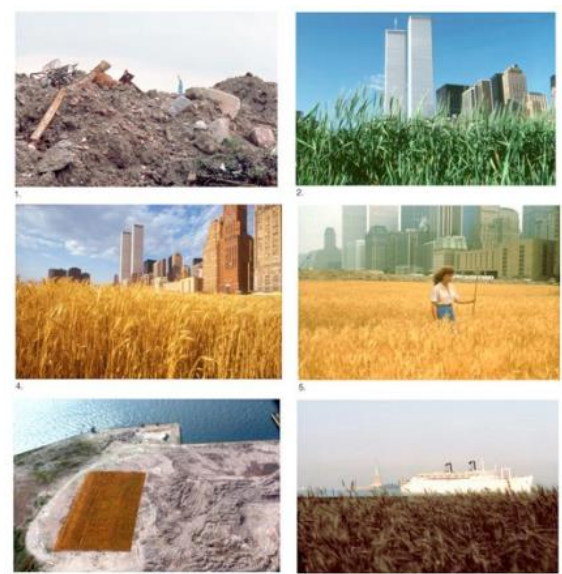

Görsel 12. Agnes Denes, Wheatfield, 1992
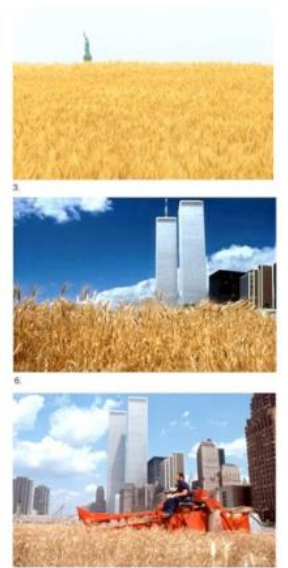

Görsel 12. Agnes Denes, Wheatfield, 1992

Sanatçıların doğayı yüceltme ve çevresel farkındalığı gündeme getirmeye dönük eylemleri günümüzde müzelerin de ilgilendiği konulardan biri olmuştur. Dünya çapında pek çok sanat kurumunun ve müzenin doğa ve ekoloji üzerine farkındalığ 1 artırmaya dönük eylemlerinin arttığı görülmektedir. Örneğin; İstanbul Modern 2016 yılında açtığı "Yok Olmadan" adlı sergi izleyenleri sürdürülebilir bir gelecek üzerine düşünmeye davet etmektedir. Sanatçıların doğaya bakışlarını sürdürülebilirlik kavramıyla ilişkilerini yansıtan çalışmalar insanın ekosistem ile etkileşimine dair yorumlar içermektedir (Eczacıbaşı, 2016). Örneğin; sergide yer alan Mark Dion'un 19. Yüzyıl ile 20. Yüzyı1 başlarına ait yaklaşık yüz adet kutup ayısı baskısı, hayvan türlerinin tükenişine ve küresel 1sınmaya, bilhassa da kutuplardaki buz tabakalarında yaşanan şiddetli erimeye gönderme yapmaktadır. Maro Michalakakos imzalı boynu bacağına dolanmış flamingo görseli ise kendimize yaptı̆̆ımız yıkımın metaforu gibidir (Bafra ve Colombo, 2016).

Sanatta çevresel hareketlerin ve ekolojik sanat üretimlerinin doğa ve insan etkileşimini destekleme, ekosisteme verilen zararı gözler önüne serme, küresel sorunlara yerel çözüm modelleri önererek ekolojik sorunlar konusunda toplumun bilincini yükseltme konusunda disiplinler arası yaklaşımla çalıştığı görülmektedir. Bu sanatçılardan bazıları çevre sorunları ile ilgili doğrudan mesaj vermeyi tercih ederken, bazıları ise mesajını dolaylı yoldan iletmektedir. Doğal çevreyle ilgili önemli konuların sanat yoluyla nasıl çözümlenebileceğini gösteren bu çalışmalar sanat eğitimi içeriklerine entegre edilmesi dünyanın mevcut koşullarının gittikçe bozulmasına istinaden her zamankinden daha önemli bir hale gelmiştir. İnsan müdahaleleri sonucu doğada onarılamayacak yıkımların geri dönüşü olamayacağı için çevresel sürdürülebilirliğin sanat eğitimi öğretim programlarında yeni bir bakış açısıyla yer bulması gerekmektedir.

\section{Sanat Yoluyla Çevre Eğitimi}

Sürdürülebilirlik ve çevre konularının eğitim programlarında kavramsallaştırılması uzun bir sürecin sonucunda gerçekleşmiştir. Kavram, 1970’lerden itibaren birçok uluslararası kuruluşun ve özellikle de Birleşmiş Milletler'in yapmış olduğu çalışmaların sonucunda biçimlenmiştir. Günümüzde sürdürülebilirlik çevre, toplum, ekonomi bağlamında birbiri ile ilişkili üç unsurla formülleştirilse de, onunla ilgili ilk algı daha çok ekolojik bir yaklaşım temelinde gerçekleşmiştir.

1970’li yıllarda dünyada özellikle sanayileşmiş bölgelerde oluşan çevre sorunlarının canlılar üzerinde yarattığı tehdit, sorunu bütüncül bir yaklaşımla ele almayı gerektirmiştir. Bu bağlamda, Birleşmiş Milletler 1972 y1lında İsveç’in başkenti Stockholm’ de “Birleşmiş Milletler İnsani Çevre Konferansı (Stockholm Konferans1)" düzenlenmiştir. Bu konferans çevre sorunlarının uluslararası perspektifte ele alınması açısından bir gündem oluşturmuştur. Konferansta kabul edilen İnsani Çevre Bildirgesi’nde, “akılcı bir eylemle hem bugünün hem de gelecek kuşakların ihtiyaçlarını karşılayan daha iyi bir çevrede yaşanabileceği, bunun için 
düzenli, gayretli ve azimli bir çalışmaya gerek olduğu" belirtilmiştir (Bozloğan, 2005). Özellikle gelişme politikalarının; ekolojik süreçlerin korunması, kaynakların sürdürülebilir kullanımı ve genetik çeşitliliğin korunması önceliğinde gerçekleştirilmesi önerilmiştir (Soussan, 1992, s. 2124). 1977 yılında gerçekleşen Tiflis Konferansı'nda ise çevre eğitiminin amaçları ve genel ilkeleri ortaya konulmuştur. Konferansta çevre eğitiminin bilinç, bilgi, tutum, beceri ve katılım boyutlarında yapılandırılmasının önemi vurgulanırken, mevcut eğitim programlarına eklenecek fazladan bir konu alanından ziyade yaşları ne olursa olsun tüm öğrencilere yönelik programlara yerleştirilmesi gerektiği belirtilmiştir (Intergovernmental Conference on Environmental Education-Sonuç Raporu (1977). 1983 yılına gelindiğinde ise, dönemin Birleşmiş Milletler Genel Sekreterinin isteği üzerine yirmi ayrı ülkeden gelen katılımcıların hazırladığı "Ortak Geleceğimiz (Brundtland Raporu)" adlı raporda, çevre ile ekonomik kalkınma arasındaki gelişmenin "sürdürülebilir" olması vurgulanmıştır. Bu konuda Birleşmiş Milletler'in bir diğer girişimi Brezilya'nın Rio de Janeiro kentinde, 3-14 Haziran 1992 tarihleri arasında 178 devletin katılımı ile gerçekleşmiştir. Birleşmiş Milletler Çevre ve Kalkınma Konferansı (Rio Konferans1)'nda sürdürülebilir kalkınma kavramının kapsamı oldukça genişlemiş, kavram birçok disiplinin çalışma alanında kendine yer edinmiştir (Bozloğan, 2005).

Tüm bu gelişmeler 1980'lerin ortalarından itibaren sürdürülebilirlik perspektifinde çevre eğitimini gündeme getirmiştir. Çevresel problemlerin asıl nedeninin insan olduğu düşüncesinden yola çıkılarak, 1990 yılında Birleşmiş Milletler'in Çevre Programı UNEP (United Nations Environment Programme), çevre eğitiminin genel çerçevesini ve anahtar kavramlarını belirlemiştir. Bunlar; "Oluşum Sistemleri (Fiziksel Yerküre, Biyosfer, Teknosfer ve Sosiosfer)", "Karmaşık Sistemler", "Nüfus Artışı ve Taşıma Kapasitesi", "Çevresel Dengeli ve Sürekli Kalkınma", "Toplumsal Dengeli ve Sürekli Kalkınma" ve "Bilgi ve Belirsizlik" şeklinde sıralamıştır (United Nations Educational, Scientific and Cultural Organization, [UNESCO] 1987). Böylelikle UNESCO'nun, 1975-1995 yılları arasında uyguladığ "Uluslararası Çevre Eğitimi Programı", "Sürdürülebilir Gelecek İçin Eğitim” programıyla değişime uğramıştır (UNESCO, 1997). Bu gelişmelere istinaden Birleşmiş Milletler tarafindan 2005-2014 yılları "Sürdürülebilir Kalkınma İçin Eğitim Onyılı" olarak ilan edilmiştir. Bu kapsamda, çevre eğitimiyle ilgili araştırmalar artmıs ve "çevresel eğitim (environmental education)", "ekoloji pedagojisi", "ekolojik öğrenme", "doğa deneyimi” ve "sürdürülebilir gelişme amaçlı eğitim" kavramlarıyla literatürde yerini almıştır (Özdemir, 2007).

Sürdürülebilir gelişme amaçlı çevre eğitimi bütünsel bir bakış açısıyla çevresel konuları, sadece biyolojik ve fiziksel parametreler ile açıklamamakta, aynı zamanda ekonomik, tarihi, kültürel, estetik, sosyal, politik bileşenleri ve bu bileşenlerin de kendi içlerinde ve kendi aralarındaki etkileşimlerini de göz önüne alarak değerlendirmektedir (Okur Berberoğlu, 2015). Bu noktada geleneksel olarak ifade edilen, insan ve doğa ilişkisini ele alan, çevreyi korumaya odaklı, bilimsel, daha çok fen eğitiminin bir alanı olarak görülen eğitim yaklaşımından (Sauve, 2005 aktaran Tanrıverdi, 2009) oldukça farklıdır. Çağdaş çevre eğitimi yaklaşımlarında, çevre bütüncül ve sosyo-kültürel bir yaklaşımla ele alınmakta ve eyleme dönük, sürdürülebilir olarak kabul edilmektedir. Diğer bir deyişle çağdaş yaklaşımlar çevre eğitiminin sadece fen boyutu olmadığı, sosyal ve kültürel boyutunun da bir o kadar etkili olduğunu savunmaktadır (Tanrıverdi, 2009). Bu bağlamda sürdürülebilir gelişim amaçlı çevre eğitimde temelde birbirinden farklı amaçları bulunan üç farklı çevre yaklaşımdan bahsedilmektedir. Bunlar; çevre hakkında (about environment) eğitim, çevre içinde (in environment) eğitim, çevre için (for environment) eğitimdir (Okur Berberoğlu ve Uygun, 2013). Bunlardan çevre hakkında eğitim, insan-çevre etkileşimi hakkında öğrenenleri bilgi sahibi yapmak, neden-sonuç ilişkilerini açıklamak ve ilgi düzeylerini arttırmaya dönük daha çok bilişsel alanı geliştirmeyi hedefleyen bir yaklaşımdır (Tilbury, 1995). Çevre içinde eğitim, sınıf dışında, daha çok öğrenci merkezli ve etkinlik merkezli eğitimler olarak kendini göstermektedir (Tilbury, 1995). Çevre için eğitim ise, çevresel ilerlemeye odaklanmaktadır. Burada bireysel sorumlulukların gelişmesi ve çevresel problemlerin çözümünde aktif katılımcı rol alma hedeflenmektedir (Okur Berberoğlu ve Uygun, 2013). 
Sürdürülebilir gelişim çözüm bulmanın yanı sıra tanımlanması bile zor oldukça karmaşık birçok sorunu içermektedir. Tüketim biçimlerini değiştirme, fakirliği azaltma, insan sağlığını koruma, toprak, su, hava ve biyo-çeşitliliği koruma, sosyal adalet ve insan hakları gibi birçok konuyu içermektedir. Sürdürülebilir ekonomi, toplum ve çevre ile yapılanan sürdürülebilir kalkınma, doğal kaynakların etkili kullanılması ve eşit bir biçimde paylaşılması ile doğrudan orantılıdır. Dolayısıyla (UNESCO, 2012) programında sürdürülebilir kalkınmanın sürdürülebilir bir çevre olmadan kesinlikle sağlanamayacağı ifade edilmektedir. Bundan ötürü günümüzde çevre eğitimi, sadece, toprak, su, orman gibi doğal kaynakların korunması biçiminde değil, ekosistemleri de kapsayacak şekilde tüm çevreyi korumak ve iyileştirmek üzerine odaklanmıştır. Ekosistemlerin nasıl işlediklerini açıklaması bakımından ekoloji, çevre eğitiminin önemli bir temel taşını oluşturmakta ve dünya vatandaşlarını çevre hakkında bilgilendirmekten öteye gidip, onları çevre yönetiminde becerileri ve gönülleri olan katılımcılar haline getirmeyi hedeflemektedir (Ünal ve Dımışk1, 1999). Bundan ötürü çevre eğitiminin sürdürülebilir bir gelecek için disiplinler arası bir boyutta ele alınması gerekmektedir. Sanat bu noktada bilinçaltında yarattığı etkiyle önemli bir yerde konumlandığı gibi, bir kültür eğitimi özelliği taşımasıyla yaşadığımız çevreyle yakından ilişkilidir. Kaldı ki, birçok sanatçının doğaya farkındalığı artırmak için disiplinler arası problem çözme modellerine başvurduğu görülmektedir. Çağdaş sanatçılarının üretimlerine bakıldığında da yeniden canlandırma, hayat verme, habitatı restore etme yoluyla sanatçıların toplumdaki rollerini yeniden yorumladıkları görülmektedir (Krug, Blandy ve Congdon, 1998). Ekolojik sanatçı Jackie Brookner “...Değerleri etkilemek, arzular yaratmak, insanların bir şeyleri önemsemesini sağlamak için insanların kalplerini, bedenlerini, bilinçdışı rüya yaşamlarını ve imgelemlerini etkilemek zorundasınızdır. Bu ise sanatın gayet iyi yaptı̆̆ bir şeydir." demektedir (aktaran Aydın ve Zümrüt, 2013, s. 64) İşte bu gerekçeyle bile sanat eğitimcileri çocuk ve gençleri bu restoratif sürece katarak onlarda çevrenin önemine dair bir farkındalık geliştirebilir.

Nitekim yeryüzünde ki ekolojik değişimlere ve çevresel felaketlere sanatçıların ilgisi sanatla ilgili tüm kurumları ve müzeleri doğa ve ekoloji üzerine projeler yapmaya ve öğretim programları hazırlamaya yöneltmiştir. Bu yönelimler çerçevesinde özellikle ABD'de Sanat ve Ekoloji: Disiplinler arası öğretim yaklaşımı (Krug, 1997) "Toplum temelli ekolojik sanat eğitimi" (Neperud, 1997), "Ekolojik sanat öğretimi” (Hollis, 1997) gibi adlandırmalarla program yapılandırma çalışmaları dikkat çekmektedir. Avrupa Birliği'ne bağlı ülkelerin sanat ve kültür eğitimine dönük öğretim programların analiz edildiği Education, Audiovisual and Culture Executive Agency [EACEA] (2009) raporu incelendiğinde de "Çevresel farkındalık ve sürdürülebilirlik" bilincine dönük ekolojiyi koruma sorumluluğunun 35 ülkeden 20'sinin öğretim programının amaçlarında yer aldığı görülmektedir. Nitekim sanat ve ekolojiyi ilişkilendirme bağlamında Neperud (1997) tarafindan yapılan bir araştırma sanat öğretmenlerinin sanatı, doğayı keşfetme ve çevre ile ilgili güçlü mesajların iletilebileceği görsel bir dil olarak çevresel konulara farkındalığın geliştirilebileceğini bir alan olarak değerlendirdikleri tespit edilmiştir.

Hollis’e (1997) göre ekolojik konularla ilişkilendirilmiş sanat öğretim programı çocukları yeryüzü ile pozitif ilişkiler kurma konusunda farkındalık kazandırabilir ve onları yıkıcı ekolojik eğilimleri değiştirme ve çevreyi korumada aktif bir ses olmalarına yardımcı olabilir. Bunun için Hollis (1997) sanat eğitimcilerinin doğru soruları sormakla işe başlanabileceğini belirtir. Örneğin;

1-İnsan doğa etkileşimlerine sanat öğretim programında nasıl yer vermeliyiz?

2-Bu etkileşimden kimler, nasıl yararlanır?

3-Etkileşimin uzun ömürlü etkileri neler olabilir?

4- İnsan-doğa etkileşimi ile birlikte yaşamda olumlu değişiklikler olabilir mi?

5-Değiştirdiğimiz şeylerin ne kadarını kontrol edebiliriz?

Hollis'e (1997) göre bu sorular sanat eğitimcilerini ekoloji temelli bir öğretim programı yapılandırmasına götürebilir. Nitekim 1997 yılında sanat eğitimi öğretim programlarının geliştirilmesine verdiği katkılarla tanınan Getty Eğitim Enstitüsü'nün desteği ile "Sanat ve Ekoloji: Öğretim Programına Disiplinler arası Yaklaşımlar” adlı program Dr. Don H. Krug 
danışmalığında pek çok eğitimci, sanat eğitimci, sanatçı ve bilim insanlarının işbirlikli çalışması sonucunda hazırlanmıştır. Bu sanat ve ekoloji programı hem çağdaş sanatçıların ekolojik kaygılarla hazırladıkları eserleri online olarak sergileyebildikleri bir ortam hem de sınıflarında ekolojik problemleri tartışmak isteyen öğretmenler için bir kaynak seti imkanı sunmuştur. Öğretim programı temel olarak 4 unsur çerçevesinde yapılandırılmıştır. Bunlar:

1. Koruma eğitimi

2. Çevresel eğitim

3. Ekoloji eğitimi ve

4. Ekolojik sanat eğitimidir.

Burada koruma eğitimi, öğrencileri orman, toprak, hava, su ve vahşi yaşamı koruma ve kaynakların yönetimi üzerine odaklarken; çevresel eğitim, çevresel sorunlara özgü çözümlerden daha çok, alternatif çözümlerin kullanımı ve sonuçlarının analizini içermektedir. Ekoloji eğitimi ise, ekolojinin canlı organizmaların birbirleriyle ve çevreleriyle ilişkilerine odaklanan bir bilim dalı olarak, doğal sistemin bütünlügü ve çeşitliliği ile ilgili konuları içine almıştır. Bu eğitim programının dördüncü unsuru olan ekolojik sanat eğitiminde ise kendi içerisinde çağdaş sanatçıların çalışma yöntemleri çerçevesinde yapılandırılmıştır. Bunlar: 1) çevre tasarımı, 2) ekolojik tasarım, 3) sosyal restorasyon ve 4) ekolojik restorasyon'dur. Burada ekolojik tasarım konusunda öğrenci Andy Goldsworty'in çalışmaları üzerinden ekolojik düşünmeye yöneltilirken, ekolojik restorasyon konusunda, Agnes Denes, Mel Chin, Mierle Laderman Ukeles gibi sanatçıların çalışmalarını analiz etmektedir. Doğa ve bilimi birleştiren bu disiplinler arası yaklaşımda sanat ve ekoloji çevresel problemleri tanımlamak için beraber çalışmaktadır. Örneğin; ekolojik konuların sanat öğretim programı ile bütünleştirilmesinde ABD'nin Ohio eyaletinde bulunan Lima West Middle School için bir öğretim etkinliği şöyle planlanmıştır.

Tablo 1

Lima West Middle School'daki ekoloji temelli bir öğretim etkinliği

Ekolojik Düşünme Ekolojik Öğretim Programı

1- Gözlem, Araştırma ve Yansitma

Sanatçılar neden ekolojik yaşam odaklı konuları ele almalıdır?
1. Ders: Çağdaş ekolojik sanat eserlerini inceleme/ tartışma ve küçük grup araştırmaları ile eserlere odaklanma

2. Ders: Ekolojik sorunları araştırma, yerel ekolojik sorunların toplum üzerindeki etkilerini araştırma/ ekolojik konularla ilgili gazete haberlerine odaklanma ilgili yetkilerle görüşme

2- Eleştirel Düşünme: Analiz etme, yorumlama ve değerlendirme

3. Ders: Ekolojik sanatın farklı biçimlerini inceleme

4. Ders: Ekolojik sanat olarak enstalasyon çalışması

Ekolojik yaşam odaklı konuların neden bir sanatçının sorumluluğu olduğunu değerlendirir.

3- Eylem haline getirme: Çizme, yazma, planlama ve üretim

Kentsel yada kırsal bölgede ekolojik problemlere nasıl yaratıcı çözümler getirebiliriz.

(greenmuseum, org)

Bu tarz ekoloji ve sanat bağlamlı araştırmalar (Garoian, 1998; Lankford, 1997) daha da artırılabilir. Örneğin; Cornelius, Sherow ve Carpenter (2010) sosyal ve doğal çevreyle ilişkili önemli konular sanat ve görsel kültür yoluyla nasıl keşfedilebilir? sorusu üzerinden yaptıkları bir araştırmada suyun insan varlığındaki önemine ilişkin öğrencilerde farkındalık kazandırmak için sınıf içinde bir etkileşim ortamı yaratmışlardır. Bunun için öncelikle suyun sosyal, kültürel, çevresel ve sağl1kla ilgili önemine, ardından çağdaş sanatçıların sanatsal bir araç olarak suyu nasıl kullandıklarına odaklanmışlardır. Bilir (2014) ise lisans düzeyinde öğrenim görmekte olan ve sanat alanı dışındaki fakültelerden gelen Seçmeli Plastik Sanatlar dersini çevresel sanat 
uygulamaları bağlamında yapılandırmıştır. Program kapsamında çağın sorunları özellikle doğaçevre ve teknoloji ilişkileri bağlamında ele alınmıştır. Öğrencilerin doğada doğal malzemelerle kurdukları sanatsal ilişkiler çalışmaların doğası gereği yardımlaşma, dayanışma, iş bölümü gibi etkileşim ortamları yarattığı gibi doğayla doğrudan bağ kurabilme olanağı yaratması ve doğaya dönük duyarlılık eğitimi yaratması açısından öğrenciler üzerinde etkili olmuştur. Diğer yandan bir sanat kurumu olan İstanbul Modern 2016 yılında gerçekleştirdiği "Yok olmadan- Doğa ve Sürdürülebilirlik Üzerine Bir Sergi" kapsamında çevresel farkındalık yaratmaya çalışan sanatçıları bir araya getirmiştir. Sergiyle paralel olarak okul gruplarına yönelik "Doğa Dostu Sanat Atölyeleri" adlı bir atölye programı hazırlamıştır. Doğayı tanıma, doğadan ilham alma ve sürdürülebilirliğe odaklanan atölye programlarında 4-12 yaş grubu çocuklara odaklanılmıştır (Eczacıbaşı, 2016). Bu gibi okul dışı öğrenme ortamlarının yaratıldığı Türkiye Bilimsel ve Teknolojik Araştırma Kurumu [TÜBİTAK], destekli bilim ve toplum projeleri kapsamında sunulan doğa ve çevre temelli projelerde de çocuklara yönelik sanat etkinliklerine gereksinim duyulduğu görülmektedir. Bu elbette ki sanatın gerçekliği betimleme, ilişkileri estetik biçimlerle anlatma ve doğaya ait gizleri öğrencilere sezdirmede ki başarısından kaynaklanmaktadır. Sanatın içsel süreçleri harekete geçirmede ki başarısı ekoloji ile sanatı entegre etme gereksinimini daha da artırmaktadır. Böylece "sezginin önü açılarak düşünce ortamından elde edilen bilginin seyahatine" (Türe, 2014, s. 227) imkân yaratılabilmektedir. Çünkü Güler'e (2009) göre bireyler ekosistemlerin işleyişi ve insan faaliyetlerinin bu sistemlerin devamlılığına yaptığı olumlu ve olumsuz etkileri öğrendikçe, doğayla ilgili daha sorumlu davranışlar geliştirmektedirler.

\section{Tartışma, Sonuç ve Öneriler}

Ülkemizde 2004 yılında yenilenen öğretim programlarıyla beraber çevre eğitimi çeşitli disiplinlerin içerisinde yer bulmuştur. Ayrıca Milli Eğitim Bakanlığı [MEB] tarafından 2015 yılında Ortaokullar için Seçmeli Çevre Eğitimi Dersi öğretim programı hazırlanmıştır. Bu programda (MEB, 2015) 1977 Tiflis Konferansı bildirisinin esasları ve UNESCO Çevre Eğitim Birimi’nin 1994 yılında sunduğu sürdürülebilir kalkınma eğitimine yönelik prototip çevre eğitim programı esas alınmıştır. Bu prototip öğretim programı kapsamında yer alan pek çok konu, disiplinler arası bir yaklaşımla Fen Bilimleri, Hayat Bilgisi ve Sosyal Bilgiler dersleri başta olmak üzere birçok dersin kapsamına alınmıştır. Ancak sürdürülebilir kalkınmanın disiplinler arası boyutu, onun ayrı bir ders olarak ele alınmasını da gerektirmiştir. Programda çevreye yerel, ulusal ve küresel bir bakış açısının gerekliliği ile kültürel ve estetik ilkeleri gözetmek özellikle vurgulanmıştır. Oldukça yeni olan bu dersin öğrenciler tarafindan ne kadar seçileceği şimdilik muammadır. Ancak mevcut koşullarda çevre ve sürdürülebilirlikle ilgili konuların Fen ve Teknoloji dersinin bir parçası olarak ele alındığı, Hayat Bilgisi ve Sosyal Bilgiler derslerinde de belli bir oranda yer bulduğu görülmektedir (Tanrıverdi, 2009). Buna karşılık Finlandiya, İrlanda gibi bazı Avrupa ülkelerinin eğitim programlarında çevre kavramının özellikle görsel sanatlar dersinde önemli bir oranda yer bulduğu görülmektedir. Ülkemizde ise Mamur ve Köksal (2016) tarafindan yapılan ilköğretim görsel sanatlar dersi öğretim programını sürdürülebilir kalkınma eğitimi perspektifinden incelenmesi sonucunda programın özellikle ve estetik bilinci destekleme, eleştirel düşünme, kültürel mirasa saygı, doğayla uyum ve onun sürekliliğine katkı sağlama gibi unsurlarla desteklendiği tespit edilmiştir. Ancak programın özellikle sürdürülebilir ekonomi ve sürdürülebilir çevre bağlamında daha güçlü bir şekilde yeniden planlanması gerektiği sonucuna varılmıştır. Nitekim Özsoy ve Ahi (2014) ilkokul çocuklarının geleceğe dönük çevre algılarını çizdikleri resimler yoluyla ortaya koymak istemişler ve araştırmada öğrencilerin çevre algıları temiz çevre, kirli çevre ve teknolojik çevre olarak üç temada kendini göstermiştir. Toplam 828 öğrencinin katılımıyla gerçekleşen çalışmada öğrencilerin büyük çoğunluğunun gelecekteki çevre algısı kirli çevre ve teknolojik çevre üzerinden hava kirliliği, toprak kirliliği, aşırı yapılaşma ve trafik olarak kendini göstermiştir. Aynı zamanda çizilen resimler çocukların çevrede yer alan canlı-cansız ögelere karşı farkındalıklarının sınırlı olduğunu göstermiştir. 
Ülkemizde sürdürülebilir yaşam göstergelerinden biri olan öğrencilerin ekolojik ayak izi farkındalıklarını artırmaya dönük (Karakaş, Doğan ve Sarıkaya, 2016) araştırmalar ile ekolojik okur-yazarlığın öğretimine ilişkin TEMA vakfı tarafından yapılan araştırma ve uygulamalar son yıllarda artmıştır. Ayrıca TÜBİTAK öğrencilerin doğa üzerinde bıraktıkları olumsuz etkilerini farkına varmalarına dönük bilim ve toplum projelerine destek vermektedir. 4004 kodlu bu projelerde amaç okul dışı etkinliklerle ve uygulamalarla çocukları bilimsel konulara odaklamaktadır. $\mathrm{Bu}$ bilim ve toplum projeleri arasında ekoloji temelli sürdürülebilir çevre eğitimini destekleyen çok sayıda proje yer almaktadır. Örneğin; doğa sevgisi ve çevre bilincini katılımcılara vermek adına Niğde Üniversitesi ve TÜBİTAK iş birliğiyle gerçekleştirilen Ekoloji Temelli Yaz Kampı Projesi'ndeki tüm etkinlikler, öğretmenleriyle beraber öğrencilerini kapsamıştır. Disiplinler arası yapılan bu projede doğa-sanat entegrasyonuna dönük etkinliklerde yer almıştır (Karataş ve Aslan, 2012).

"İnsanlığın doğayı sömürmesi ve hükmü altına alması gerektiği yolundaki temel kavrayış insanın insan üzerindeki tahakkümü ve sömürüsünden kaynaklanır" (Bookchin, 2013, s. 62). İşte ekoloji tamda bu noktada insanlığın doğal dünyayla ilişkisine odaklanan bir bilim alanı özelliği taşımaktadır. "Hem biyolojik hem de sosyolojik boyutlara sahiptir" (Lankford, 1997). Dolayısıyla "ekolojik sanat da çevre üzerine entelektüel bir derinliği içinde barındırarak insanın çevresindeki organik yaşamla bütünleşmesini” (Türe, 2013, s. 236) amaçlamaktadır Sanatç1, doğada var olan ekolojik ve çevresel değeri kelime ve sözlerin sınırlılı̆̆ından sınırsız algılanabilirlik seviyesine transfer edebilme gücüyle, insanların ve toplumun farkındalıklarını arttırabilmektedir (Caddy, 2013). Genellikle görsel ve estetiksel algılama ölçütleri bağlamında yapılandırılan sanat çalışmaları mesajını duyurmada ve sezdirmede daha etkili olabilmektedir. Dolayısıyla bilimsel bilginin iletimi duyular yoluyla algılanan kadar kolay ya da kendiliğinden gerçekleşmeyebilmektedir. Bu noktada görsel sanatların ve görsel sanatlar eğitiminin çevre üzerine farkındalık yaratmak, insanları onun üzerine düşündürmek ve eyleme geçirmek konusunda etkisi tartışılmazdır. Bu nedenle öğretmenler sanat derslerinde ekoloji üzerine çalışan sanatçıların çalışmalarına odaklanarak, onların çalışmalarındaki çeşitli yaklaşımları ve temaları keşfetmelerini sağlayabilirler. Böylelikle yerel ve küresel ölçekte ekoloji ile ilgili konularda problem çözme, değerleri, düşünce ve fikirleri ifade etme ve farkındalığ 1 artırma yoluyla onları çevre üzerine yaratıcılığa yöneltebilirler. Bunun için sanat öğretim programlarında öğrencilerin; çevrelerindeki birbiriyle ilişkili boyutlara farkındalığını geliştirmek, yerel ve küresel çevrenin bütünlüğü ile ilgilenmek ve çevre koşullarını iyileştirme duyarlığı ve sorumluluğu geliştirmeye dönük amaçların daha fazla yer bulması gerekmektedir. Ancak sanat derslerinde ekolojik konuların daha fazla yer bulması için;

a) Okullarda çevreyle ilgili diğer disiplin alanlarıyla ortak projeler hazırlanabilmesi için fonlar ayrilmas1,

b) Öğrencilerin biyolojik çeşitlilik ve toprakla etkileşime girmesi kapsamında ekolojik çözümler getirilmesi,

c) Çevre eğitiminin okul dışı boyutunun göz ardı edilmeden öğrencilerin park, bahçe gibi doğal alanlarla buluşturulması ve bu alanlara yönelik sanat projeleri geliştirilmesi,

d) Öğretmen eğitim programları ve ders öğretim programlarının sürdürülebilir kalkınma eğitimi perspektifinde yeniden düzenlenmesi yararlı olacaktır.

\section{Kaynaklar}

Antmen, A. (2010). 20. Yüzyıl sanatında akımlar. İstanbul: Sel Yayıncılık.

Ataseven, O. (2016). Heykelin çevresel serüveni. SDU ART-E Güzel Sanatlar Fakültesi Sanat Dergisi, 9(17), 262-277.

Aydın, İ. ve Zümrüt, Y. (2013). Doğa ve sanat ekseninde farklı yaklaşımlar, Anadolu Üniversitesi Sanat ve Tasartm Dergisi, 4, 53-65.

Bafra, Ç. ve Colombo, P. (2016). Yok olmadan. C. Kantarcı (Yay. haz.) Yok olmadan doğa ve sürdürülebilirlik üzerine bir sergi içinde (s. 15-26). İstanbul: İstanbul Modern.

Bianco, A. (2000). Ecological art and ethics. Erişim adresi: http://ecologicalart.org/ ecartandet.html 
Bilir, A. (2014). Plastik sanatlar eğitiminde çevresel sanat uygulamaları, Anadolu Üniversitesi Sanat ve Tasartm Dergisi, 6, 20-41.

Blandy, D., Congdon, K. G. ve Krug, D. H. (1998). Art, ecological restoration and art education, Studies Art Education, 39(3), 230-243.

Bookchin, M. (2013). Ekolojik bir topluma doğru. (A. Y1lmaz, Çev.) İstanbul: Sümer Yayınc1lik.

Bozloğan, R. (2005), Sürdürülebilir gelişme düşüncesinin tarihsel arka planı. Argos Yeryüzü Kültürü Dergisi, 33, 1012-1028.

Bower, S. (2010). A profusion of terms, Erişim adresi: http://greenmuseum.org/generic_content. php?ct_id=306.

Caddy J. (2013). The confluence of art and ecology, Erişim adresi: http://www.morningearth.org/Graphic-E/BIOSPHERE/Bios-Sp- EcoFunctionArt.ht

Cornelius, A., Sherow, E. ve Carpenter, B.S., II. (2010). Water: Social issues and contemporary art education. Art Education, 63(6), 25-32).

Eczacıbaşı, O. (2016). Sunuş. C. Kantarcı (Yay. haz.) Yok olmadan doğa ve sürdürülebilirlik üzerine bir sergi içinde (s. 7-9). İstanbul: İstanbul Modern.

Education, Audiovisual and Culture Executive Agency. (2009). Avrupa'da okullarda sanat ve kültür eğitimi. Erişim adresi: http://www.eurydice.org

Denes, A. (2015). Buğday sanatla büyüyor (Görüşme). Tarla Sera Ayllk Tarım ve Kültür Dergisi. Erişim adresi: http://www.tarlasera.com/haber-8840-bugday-sanatla-buyuyor

Garoian, C. R. (1998). Art education and the aesthetics of land use in the age of ecology, Studies in Art Education, 39(3), 244-261.

Grandle, S. (2007). Ecology of place: Art education in a relational world. Studies in Art Education -Special Issue on Eco-Responsibility in Art Education, 48(4), 392-411.

Güler, T. (2009). Ekoloji temelli bir çevre eğitiminin öğretmenlerin çevre eğitimine karş1 görüşlerine etkileri. Ë̆itim ve Bilim, 151(34), 30-43.

Heinberg, R. (2016). Neden sürdürülebilirlik? C. Kantarc1 (Yay. haz.) Yok olmadan doğa ve sürdürülebilirlik üzerine bir sergi içinde (s. 27-36). İstanbul: İstanbul Modern.

Hollis, C. L. (1997). On developing an art and ecology curriculum, Art Education, 50(6), 21-24.

Intergovernmental Conference on Environmental Education-Final Report (1977). UNESCOUNEP. Tiflis:14-26 Ekim 1977. Erişim adresi: http://www.gdrc.org/uem/ee/ EETbilisi_1977.pdf

Karataş, A. ve Aslan, G. (2012). İlköğretim öğrencilerine çevre bilincinin kazandırılmasında çevre eğitimin rolü: Ekoloji temelli yaz kamp1 projesi, ZFWT Journal of World of Turks, 4(2), 259-276.

Karakaş, H., Doğan, A. ve Sarıkaya, R. (2016). Etkinlik temelli eğitimin üstün yetenekli öğrencilerin ekolojik ayak izi farkındalığına etkisi. Turkish Studies International Periodical for the Languages, Literature and History of Turkish, 11(3), 1365-1386.

Lankford, L. E (1997). Ecological stewardship in art education, Art Education, Special Issues: Art And Ecology, 50(6), 47-53.

Milli Eğitim Bakanlı̆̆ı. (2015). Çevre eğitimi dersi öğretim programı. Erişim adresi: http://ttkb.meb.gov.tr/program2.aspx

Neperud, R. W. (1997). Art, ecology ve art education: Practices and linkages. Art Education, 50(6), 14-20.

Mamur, N. ve Köksal, N. (2016). Görsel sanatlar öğretim programının sürdürülebilir kalkınma eğitimi bağlamında incelenmesi. Bartın Üniversitesi Eğitim Fakültesi Dergisi, 5(3), $732-747$.

Oğuz, D. (2015). Sanat perspektifinden çevre sorunları. Anadolu Üniversitesi Sanat ve Tasarım Dergisi, 8, 48-61.

Okur Berberoğlu, E. ve Uygun, S. (2013). Tübitak 4004 projelerinin sürdürülebilir kalkınma için çevre eğitimi kapsamında değerlendirilmesi. Abant İzzet Baysal Üniversitesi Ĕ̈itim Fakültesi Dergisi, 13(2), 107-133. 
Okur Berberoğlu, E. (2015). Öğretmenlerin bütünsel bakış açısına dayalı ekopedagoji temelli çevre eğitimine ilişkin görüşleri. Mersin Üniversitesi Eğitim Fakültesi Dergisi, 11(3), $732-751$.

Özdemir, O. (2007). Yeni bir çevre eğitimi perspektifi: Sürdürülebilir gelişme amaçlı eğitim, Eğitim ve Bilim, 32(145), 23-39.

Özsoy, S. ve Ahi, B. (2014) İlkokul öğrencilerinin geleceğe yönelik çevre algılarının çizdikleri resimler aracılığı ile belirlenmesi. Kuram ve Uygulamada Eğitim BilimleriEducational Sciences: Theory \& Practice, 14(4), 1557-1582.

Stankiewicz, M. A. ve Krug, D. H. (1997). Art and ecology, Art Education, 50(6), 4-5.

Soussan, J. G. (1992). Sustainable development. M. Mannion ve S. R. Bowlby (Yay. haz.). Environmental Issues in the 1990's içinde (s. 21-35). A, John Wiley \& Sons, West Sussex, England.

Tanrıverdi, B. (2009). Sürdürülebilir çevre eğitimi açısından ilköğretim programlarının değerlendirilmesi. Ĕ̈itim ve Bilim, 34(151), 89-103.

Tilbury, D. (1995). Environmental education for sustainability: Defining the new focus of environmental education in the 1990s. Environmental Education Research, 1(2), 195212.

Türe, C. (2013). A methodology to analyse the relations of ecological footprint corresponding with human development index: Eco-sustainable human development index. International Journal of Sustainable Development \& World Ecology, 20(1), 9-19.

Türe, C. (2014). Küresel iklim değişikliğinin toplumsal algısında görsel sanatların rolü. Anadolu Üniversitesi Sanat ve Tasarm Dergisi, 6, 224-239.

The United Nations Economic Commission for Europe, (2009). The UNECE strategy for education for sustainable development, United Nations: New York and Geneva. Erişim adresi: https://sustainabledevelopment.un.org/content/documents/798ece5.pdf

United Nations Educational, Scientific and Cultural Organization, (1987). International strategy for action in the field of environmental education and training for the 1990s. Erişim adresi: http://unesdoc.unesco.org/images/0008/000805/080583eo.pdf

United Nations Educational, Scientific and Cultural Organization, (1997). Educating for a sustainable future. A transdisciplinary vision for concerted action. Paris: UNESCO. Erişim adresi: http://www.unesco.org/education/tlsf/mods/theme_a/popups/ mod01t05s01.html

United Nations Educational, Scientific and Cultural Organization, (2005). United Nations decade of education for sustainable development (2005-2014): International implementation scheme, Paris: UNESCO. Erişim adresi: https://www.bibb.de/ dokumente/pdf/a33_unesco_international_implementation_scheme.pdf

United Nations Educational, Scientific and Cultural Organization, (2012). Education for sustainable development. Paris: United Nations Educational Scientic and Cultural Organization, Erişim adresi: https://sustainabledevelopment.un.org/content/ documents/926unesco9.pdf

Ünal, S. ve Dımışkı, E. (1999). UNESCO-UNEP himayesinde çevre eğitiminin gelişimi ve Türkiye'de ortaöğretim çevre eğitimi. Hacettepe Üniversitesi Eğitim Fakültesi Dergisi, 16-17, 142-154.

Y1lmaz, M. (2013). Modernden postmodernizme sanat. Ankara: Ütopya Yayınları.

\section{Görsel Kaynaklar}

Görsel 1. Roberth Smithson, "Spiral Jetty". (1970). Erişim adresi: http://dunyalidergi.com /index.php /uzaydan-gorunen-sanat-eserleri/

Görsel 2. Joseph Beuys, “7000 Oaks 7000 Basalt”. (1982-1987). Erişim adresi: http://design.walkerart.org/tree/

Görsel 3. Andy Goldsworthy, "Snowballs". (200). Erişim adresi: https://tr.pinterest.com /pin/401664860495948274/ 
Görsel 4. Andy Goldsworthy, "Emhemeral Works". (2004-2014). Erişim adresi: http://www.npr.org/2015/10/08/446731282/sculptor-turns-rain-ice-and-trees-into-ephemeralworks

Görsel 5. Lynne Hull, "Lightning Raptor Roost". (1994). Erişim adresi: http://www.dailyartfixx.com/2011/04/22/earth-day-2011-environmental-artists-making-adifference/

Görsel 6. Lynne Hull, “Wildlife Wraning Signs”. (2009) Erişim adresi: https://mccollcenter.org/artists-in-residence/lynne-hull

Görsel 7. Helen ve Newton Harrison, "Green Zone". (2009) Erişim adresi: http://newsgrist.typepad.com/underbelly/2008/12/helen-and-newton-harrison-to-speak-ronaldfeldman-gallery.html

Görsel 8. Mierle L. Ukeles, "Flow City". (1983). Erişim adresi: http://www.greenmuseum.org /c/aen/Issues/ukeles.php

Görsel 9. Mel Chin, "Revival Field". (1990). Erişim adresi: http://greenmuseum.org/ c/aen/Issues/chin.php

Görsel 10. Yoko Ono, “Ex It”. (1997-2007). Erişim adresi: http://filmhafizasi.com/yokolmadan-istanbul-modernde/

Görsel 11. Nele Avezedo, "Melting Men”. (2009). Erişim adresi: https://cup2013.wordpress.com/tag/nele-azevedo/

Görsel 12. Agnes Denes, "Wheatfield". (1992). Erişim adresi: http://www.agnesdenesstudio.com/works7.html

Görsel 13. Maro Michalakos, "Untitled". (2014). Erişim adresi: http://www.cevreciyiz.com/ haber-detay/5630/yok-olmadan-doga-ve-surdurulebilirlik-uzerine-bir-sergi

\section{Extended Abstract}

\section{Introduction}

In the 20th century, scientific and technological advances along with the modern society's notso-environmental-friendly development and human centered approaches have reflected on cultural and economical values and have led the world into an ecological crisis. Since the mid 20th century, many environmental problems such as global warming, pollution of fresh water bodies, the extermination of forestry and farming lands, erosion, population increase, new diseases and hunger thread have become the main topic of conversations. As the artists could not be indifferent to the potential risks in social life created by consumption and rapid growth focused approaches on the environment and human beings, they opened environmental problems up for discussion through interdisciplinary approaches in their works of art.

\section{Method}

This study particularly focuses on the pieces of artists who directly give messages about environmental issues or invite people to think about sustainability. Within the scope of a descriptive analysis on artists' work such as Joseph Beuys, Yoko Ono, Andy Goldsworthy, Mierle Ukeles, David Hansen, Mel Chin, Maro Michalakakos the aim was to draw people's attention to environmental responsibilities through ecology and sustainable art practices. In this study, after the artists' works were analyzed in general based on the issues they work on, evaluations were made about how sustainability and ecological issues could be handled on theory and application level in art education.

\section{Result and Discussion}

It is seen that environmental moves in art and ecological art production work through an interdisciplinary approach in the fields of supporting nature and human interaction, displaying the harm given to ecosystem, raising public consciousness in the subjects of ecological 
problems by offering local solution models to global problems. While some artists prefer giving direct messages about the environmental problems, others prefer conveying their messages in a roundabout way. As the existing conditions in the world keep deteriorating, it has become more important to integrate these art works that show how to solve important issues related to natural environment into educational content. As the destructions on nature due to human intervention are irremediable, environmental sustainability should find a place in art education programs with a new point of view. Thus, the interest of the artists over ecological changes and environmental disasters has directed all institutions related to art and museums to design projects and prepare teaching programs about nature and ecology. Within the frame of these trends, particularly in the USA, Art and Ecology: Interdisciplinary teaching approach (Krug, 1997) has attracted attention with program configuration studies named as "Community based ecological art education" (Neperud, 1997) and "Ecological art teaching" (Hollis, 1997). When analyzed, it is seen in EACEA report (2009) that which analyzes the art and culture education teaching programs of the EU countries, 20 of 35 countries' teaching programs include ecological protection responsibility which is related to "Environmental awareness and sustainability". As a matter of fact, in a study carried by Neperud (1997), it is determined that art teachers see art as a visual language which can convey strong messages related to exploring nature and environment, and expand awareness related to environmental issues.

Art works which are usually structured in the context of visual and aesthetical perception could be more effective in conveying and implicating their messages. Therefore, transmission of scientific knowledge might not be as easy and automatically as perceiving through senses. At this point, the effects of visual arts and visual arts education on raising awareness about environment, making people ponder about it and making it happen are indisputable. Thus, by focusing on the works of artists that work on ecology, teachers can make students discover the various approaches and themes in these artists' work in their art classes. So they can direct their students to creativity about environment through problem solving about ecology in local and global scale, stating their ideas and raising awareness. To achieve this aim, it is necessary to make room in art teaching programs for the aims to raise awareness of the students about dimensions in the environment that are related to one another, deal with the integrity of local and global environment and improve susceptibility and responsibility to improve environmental conditions. Particularly in art lessons, for ecological issues to find more place, it is thought that it is effective to meet students with natural areas such as parks and gardens without overlooking the extra scholastic dimension of the environment education and to develop art projects related to these areas. Moreover, it is beneficial to re-regulate teacher training programs and programs of instruction in the perspective of sustainable development education. 